\title{
Determinations of adaptation level of wine grape varieties in terms of climatic data in wine growing regions of turkey
}

\author{
Fadime Ateş ${ }^{\mathrm{a}}$ and Hülya Uysal \\ Manisa Viticulture Research Institute Manisa, Turkey
}

\begin{abstract}
Wine grapes are adapted to a wide range of climate; the best production occurs in regions that meet certain specific climatic conditions. Temperatures during the growing season can affect grape quality and viability. Beneficial climatic conditions will improve the wine's quality. In this study it is aimed that to determine suitable wine grape varieties for the cultivation in some areas of Southeastern Anatolia Region, Eastern Anatolia, Central Anatolia Region, Central Black Sea Region, Aegean Region and Marmara Region in Turkey with related to climate requirements. For this reason, long-term climatic data were collected by meteorological stations including, Diyarbakır (Çermik, Çüngüş), Central-Elazı̆̆ Nevşehir (Central and Ürgüp), Ankara (Kalecik) Tokat (Central, Erbaa, Niksar, İzmir (Seferihisar, Menderes, Urla) ve Denizli (Çal ve Güney), Çanakkale (Bozcaada, Bayramiç), Tekirdağ. In this study heliotermic and hdyrothermic indices were calculated and evaluated for appropriate viticultural practice in this region. It was found that Boğazkere and Öküzgözü in Southeastern Anatolia Region and Eastern Anatolia Region; Kalecik Karas1, Dimrit and Narince in Central Anatolia Region and Emir in Central Black Sea Region; Bornova Misketi, Cabernet Sauvignon, Syrah, Alicante Bouschet, Carignane, Kalecik Karası, Merlot, Öküzgözü, Çal Karası, Boğazkere, Sultani Çekirdeksiz in Aegean Region; Karasakız,Karalahana, Vasilaki, Cabernet Sauvignon, Merlot, Syrah, Alicante Bouschet, Semillion, Cinsaut, Yapıncak, Gamay, Merlot, Cabernet Sauvignon can be adapted and grown well in terms of climatic conditions in Marmara Region respectively.
\end{abstract}

\section{Introduction}

Turkey has a very rich genetic potential as it is the gene center of grapevine.

Turkey is a major producer of grapes in the world and viticulture is one of the major branches of agriculture with respect to production area and its large share of income in Turkish national economy. Grapevine is grown in almost all parts of Turkey and has been produced commercially in many regions of the country for many years.

Turkey is among the important viticulturist countries with its 478.000 ton of viticulture field and 4, 26 millions of ton of grape production. (5th one for the area and 6th one in the production) $52.9 \%$ of table grape, $36.3 \%$ to be dried, $10.8 \%$ for wort and wine [1].

The climatic conditions have a very important role in the constitution of the maturity, yield and quality values of the wine grape variety. The criterias determining the relations between the Vitis vinifera and the climate and if the substrate is convenient for the grape vine farming cultivation have been presented in the studies [2-7]. Specific temperature data are the basic information for any grape variety. Reaching to the phonologic phases, key for any varieties, is possible when $10^{\circ} \mathrm{C}$ heat accumulation is used as base. [8,8-10]. Each variety of grapes needs a specific heat accumulation starting from the beginning of the vegetation period until the maturity period [9]. Maturity period of grapes is closely connected to the local

$\bar{a}$ e-mail: fadime.ates@tarim.gov.tr climate conditions and phenological growth of the variety. Phenological growth is a genetic feature varies from variety to variety [8]. It has been detected that effective heat summation demand is between $1210^{\circ} \mathrm{C}$ (Cardinal) and $1500^{\circ} \mathrm{C}$ (Müssküle) in Ankara conditions; $1033^{\circ} \mathrm{C}$ (Uslu) and $1538^{\circ} \mathrm{C}$ (Alphonse L.) in Mediterranean conditions [11]. If a grape variety cannot mature its grape in the demanded level in ecology, it means that it cannot be recommended to be cultivated for hot region.

Oraman [12], has emphasized in the study that he has performed that regular sunshine duration is important as well as the temperature and that the annual sunshine duration of a grape wine should not be less than 1300 hours. According to Çelik et all [13] this value should not be less that 1500-1600 hours in an economical grape wine cultivation and that the vegetation duration must be more that 180 days. Other conditions apart from the vegetation are also important in the grape variety choice of regions (especially in the regions with frost risk). The resistances of the grape varieties to the lower temperatures are very different. Accordingly, it has been detected in the studies held that if the temperature is lower than $-20,5^{\circ} \mathrm{C}$ in 3 or less times 10 years, that region is convenient for the grape wine cultivation [13] Not only the heat accumulation but also sunshine and amount of precipitation should also be taken into the consideration for the convenience to the environment during the vegetation period of a grape variety. according to [2-4,14]. Karantonis [14] the temperature values of the environment is not the unique important factors for the grape cultivation; what is really 
important is the balance between the temperature and sunshine. It is stated that the heliothermic proportion $\left(\mathrm{X}^{*} 12-3 / \mathrm{H}^{*} 10-3\right)$ value 1 or higher environments are convenient for the grape cultivation. The method of detecting the varieties that might be convenient in a specific area by studying the relations between Grape varieties and environmental conditions (climate, land) has been applied in many countries of the world.

The grape varieties that might be cultivated according to the climate data of the Aegean Region and Marmara Region have been detected with the studies that have been held in our country. To improve the wine grape cultivation in Aegean Region, the climate factors of the region have seen to have accorded with the region. The studies regarding the detection not only the domestic wine grape but also qualified wine grapes of foreign origins have gained a lot importance in the recent years.

The objective of this study was to determine suitable wine grape varieties for the cultivation in some areas of Southeastern Anatolia Region, Eastern Anatolia, Central Anatolia Region, Central Black Sea Region, Aegean Region and Marmara Region in Turkey with related to climate requirements.

\section{Materials and methods}

\subsection{Materials}

In this study was the first group material was provided wine grape growers in Diyarbakır (Çermik, Çüngüş), CentralElazı $\breve{g}$ provinces of the Southeastern Region; Nevşehir (Central and Ürgüp), Ankara (Kalecik) provinces of the in Central Anatolia Region; Denizli (Güney and Çal) and İzmir (Menderes, Seferihisar, Urla) provinces of the Aegean Region; Çanakkale (Bozcaada, Bayramiç), Tekirdağ provinces of the Marmara Region. Other materials consist of the climatic data (temperature, rain etc) of long years provided from the meteorological stations of the counties.

\subsubsection{Experimental site}

Çermik and Çüngüş counties in Diyarbakır provinces of the Southeastern Anatolia region; Central-Elazı $\breve{g}$ in Elazı $\breve{g}$ provinces of the Eastern Anatolia region, being the study area has $3681 \mathrm{~km}^{2}$ of total area. Wine grape area of the examined study area is 53950 decare and total wine grape production amount is 43753 tons (Table 1). Central-Elazı $\breve{g}$ county has the largest viticulture field (37100 decare) and it is Central-Elazı $\breve{g}$ county that has the furthest production amount (33245 tons). Average yield of the study area is $749 \mathrm{~kg} /$ decare (Table 1).

Central-Nevşehir and Ürgüp counties in Nevşehir provinces; Kalecik counties in Ankara provinces of Central Anatolia Region region; Central-Tokat, Erbaa and Niksar in Tokat provinces of the Eastern Anatolia region, being the study area has $6461 \mathrm{~km}^{2}$ of total area. Wine grape area of the examined study area is 105803 decare and total wine grape production amount is 72234 tons (Table 1). CentralNevşehir county has the largest viticulture field (29900 decare) and it is Central-Nevşehir county that has the furthest production amount (23920 tons). Average yield of the study area is $661 \mathrm{~kg} /$ decare (Table 1).

Güney and Çal counties in Denizli provinces; Menderes, Seferihisar and Urla counties in İzmir provinces of the Aegean region, being the study area has $329 \mathrm{~km}^{2}$ of total area. Wine grape area of the examined study area is 87200 decare and total wine grape production amount is 48750 tons. (Table 1) Çal county has the largest viticulture field (400000 decare) and it is Güney county that has the furthest production amount (21250 tons). Average yield of the study area is $562 \mathrm{~kg} /$ decare (Table 1).

Bozcaada and Bayramiç counties in Çanakkale provinces; Şarköy counties in Tekirdağ provinces of the Marmara region, being the study area has $1793.6 \mathrm{~km}^{2}$ of total area. Wine grape area of the examined study area is 42320 decare and total wine grape production amount is 33955 tons (Table 1). Şarköy county has the largest viticulture field (20000 decare) and it is Şarköy county that has the largest production amount (5625 tons). Average yield of the study area is $820 \mathrm{~kg} /$ decare (Table 1).

\subsection{Methods}

Çermik and Çüngüş counties in Diyarbakır provinces of the Southeastern Anatolia region; Central-Elazı $\breve{g}$ in Elazı $\breve{g}$ provinces of the Eastern Anatolia region; Central -Nevşehir and Ürgüp counties in Nevşehir provinces; Kalecik counties in Ankara provinces of Central Anatolia Region region; Central-Tokat, Erbaa and Niksar in Tokat provinces of the Eastern Anatolia region; Güney and Çal counties in Denizli provinces; Menderes, Seferihisar and Urla counties in İzmir provinces of the Aegean region; Bozcaada and Bayramiç counties in Çanakkale provinces; Şarköy counties in Tekirdağ provinces of the Marmara region had been the sampling area. The counties have been chosen so as to provide $50 \%$ of the wine grape production. 40 Wine grape growers from each county have been interviewed with telic sampling method.

'Effective heat summation (EHS)', being one of the efficient parameters to determine the needs of the wine grape varieties in the specific region, has been calculated. In the calculation of this value expressed as Day-Temperature, $10^{\circ} \mathrm{C}$ (threshold temperature), which is accepted as the average temperature when the grape wine growth starts, has been selected as baseline (Çelik and, 1998). The assessments have been formulated as the date and day when the average of many years in several stations for $10^{\circ} \mathrm{C}$, threshold of the grape vine growth, reaches to threshold temperature (end date and day of the vegetation) and the accumulation of the temperatures that the average temperature for each day in this period is higher that the threshold temperature.

$$
\begin{aligned}
& \text { EHS }=\sum(\mathrm{T}-\mathrm{Te}) \\
& \text { EHS }=\text { accumulation of the effective temperature } \\
& \left({ }^{\circ} \mathrm{C}\right. \text {-day) } \\
& \mathrm{T}=\text { daily average temperature }\left({ }^{\circ} \mathrm{C}\right) \\
& \text { Te: threshold temperature }\left({ }^{\circ} \mathrm{C}\right) .
\end{aligned}
$$

Hydrothermic indices was calculated to determine the possibility of supplying the water need of the grape vine from the natural ways. In this calculation it will be determined that if the water consummation related to the temperature change of the varieties in the May-July period and rain, can be provided from the natural ways.

$$
\begin{aligned}
& \text { Hydrothermic indices: }\left(\sum \mathrm{P}^{*} 10\right) / \sum \mathrm{T}^{\circ} \\
& \sum \mathrm{P}=\text { Total rain }(\mathrm{mm}),
\end{aligned}
$$


Table 1. Surface area of the counties $\left(\mathrm{km}^{2}\right)$, viticulture area (decare), production (ton) and yield (kg/ decare) values (Anonym, 2010).

\begin{tabular}{|c|c|c|c|c|c|}
\hline REGIONS & COUNTIES & $\begin{array}{c}\text { Surface area } \\
\text { of the } \\
\text { counties } \\
\left(\mathbf{k m}^{2}\right)\end{array}$ & $\begin{array}{c}\text { Viticulture } \\
\text { area } \\
\text { (decare) }\end{array}$ & $\begin{array}{l}\text { Production } \\
\text { (ton) }\end{array}$ & $\begin{array}{c}\text { Yield } \\
\text { (kg/decare) }\end{array}$ \\
\hline \multirow{4}{*}{ 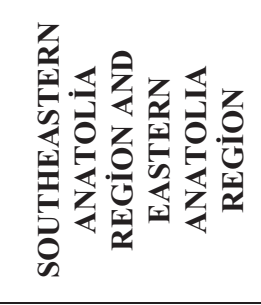 } & $\begin{array}{l}\text { Çermik- } \\
\text { DIYYARBAKIR }\end{array}$ & 991 & 6850 & 6508 & 950 \\
\hline & $\begin{array}{l}\text { Çüngüş- } \\
\text { DİYARBAKIR }\end{array}$ & 472 & 10000 & 4000 & 400 \\
\hline & $\begin{array}{l}\text { Central- } \\
\text { ELAZIG } \\
\end{array}$ & 2218 & 37100 & 33245 & 896 \\
\hline & TOTAL & 3681 & $\mathbf{5 3 9 5 0}$ & 43753 & 749 \\
\hline \multirow{7}{*}{ 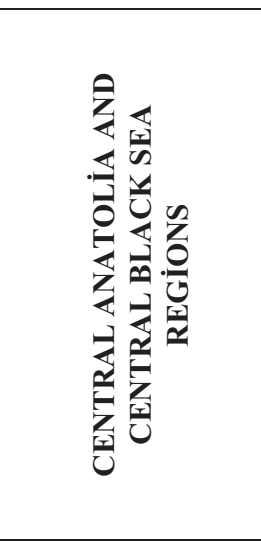 } & $\begin{array}{l}\text { Central - } \\
\text { NEVSEHIR }\end{array}$ & 536 & 29900 & 23920 & 800 \\
\hline & $\begin{array}{l}\text { Ürgüp- } \\
\text { NEVSEHIR }\end{array}$ & 565 & 31950 & 19726 & 617 \\
\hline & $\begin{array}{l}\text { Kalecik- } \\
\text { ANKARA }\end{array}$ & 1341 & 8500 & 5525 & 650 \\
\hline & $\begin{array}{l}\text { Central - } \\
\text { TOKAT }\end{array}$ & 1924 & 17910 & 12537 & 700 \\
\hline & $\begin{array}{l}\text { Erbaa- } \\
\text { TOKAT }\end{array}$ & 1177 & 11493 & 6896 & 600 \\
\hline & $\begin{array}{l}\text { Niksar- } \\
\text { TOKAT }\end{array}$ & 918 & 6050 & 3630 & 600 \\
\hline & TOTAL & 6461 & 105803 & 72234 & 661 \\
\hline \multirow{6}{*}{ 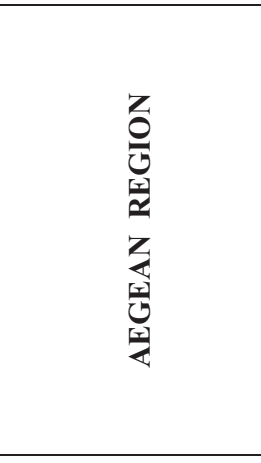 } & $\begin{array}{l}\text { Menderes- } \\
\text { İZMİR }\end{array}$ & 775 & 96500 & 7720 & 800 \\
\hline & $\begin{array}{l}\text { Seferihisar- } \\
\text { IZMMIR }\end{array}$ & 371 & 32500 & 2600 & 800 \\
\hline & $\begin{array}{l}\text { Urla- } \\
\text { İZMİR }\end{array}$ & 728 & 8000 & 2200 & 150 \\
\hline & $\begin{array}{l}\text { Güney- } \\
\text { DENIZLI }\end{array}$ & 534 & 290000 & 21250 & 691 \\
\hline & $\begin{array}{l}\text { Çal- } \\
\text { DENIZLII }\end{array}$ & 1521 & 400000 & 14800 & 370 \\
\hline & TOTAL & 3929 & 827000 & 48570 & 562 \\
\hline \multirow{5}{*}{ 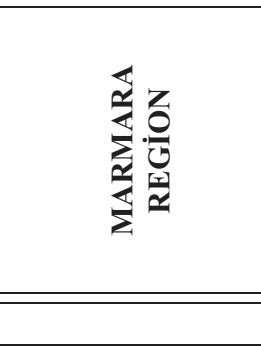 } & $\begin{array}{l}\text { Bozcaada- } \\
\text { ÇANAKKALE }\end{array}$ & 37.6 & 6420 & 5625 & 900 \\
\hline & $\begin{array}{l}\text { Bayramiç- } \\
\text { ÇANAKKALE }\end{array}$ & 1275 & 15900 & 11130 & 700 \\
\hline & $\begin{array}{l}\text { Şarköy- } \\
\text { TEKİRDAG }\end{array}$ & 481 & 20000 & 17200 & 860 \\
\hline & TOTAL & $\mathbf{1 7 9 3 . 6}$ & 42320 & 33955 & 820 \\
\hline & TOTAL & 15864,6 & 1029073 & 198512 & 698 \\
\hline
\end{tabular}

Heliothermic indices have been calculated to determine the balance between the temperature and sunshine for the grape production.

Heliothermic indices: $\mathrm{X}^{*} 12^{-3} / \mathrm{H}^{*} 10^{-3}$

$\mathrm{X}$ : accumulation of the effective heat temperature during the vegetation period

$\mathrm{H}$ : total hours of days (daytime).

\section{Results and discussion}

Diyarbakır (Çermik and Çüngüş) and Elazı̆̆ (CentralElazı $\breve{g})$ two of the cities where important wine grapes are being produced in the Southeastern Anatolia Region and Eastern Anatolia Region, have been the study area. Terrestial level varies from 29.2 (Central-Elazı $\breve{g})-30.1$ (Çüngüş) according to the geographic and topographic conditions of the study area. The effects of the variety of the terrestial level, annual total rain and altitude difference have been observed. Average temperature value of the study area for many years have been measured between $14.6^{\circ} \mathrm{C}$ (Menderes) and $16.5^{\circ} \mathrm{C}$ in Çermik (Table 2). Extremely high temperature values are between $42.2^{\circ} \mathrm{C}$ (Central-Elazı ğ) and $46.1^{\circ} \mathrm{C}$ (Çermik). Peak value of the low temperatures varies between $-23.4{ }^{\circ} \mathrm{C}$ (Çermik) and $-22.6^{\circ} \mathrm{C}$ (Central-Elazı $\left.\breve{g}\right)$ (Table 2). 


\begin{tabular}{|c|c|c|c|c|c|c|c|c|c|c|c|c|c|c|c|c|c|}
\hline 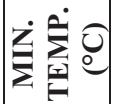 & $\stackrel{\vec{\vartheta}}{\ddot{i}}$ & $\begin{array}{l}\infty \\
\underset{\sim}{\sim}\end{array}$ & $\begin{array}{l}0 \\
\stackrel{i}{i}\end{array}$ & $\stackrel{\sim}{\vec{T}}$ & $\stackrel{\vec{i}}{i}$ & $\stackrel{+}{\vec{T}}$ & $\overrightarrow{\mathrm{i}}$ & $\overrightarrow{\grave{i}}$ & $\vec{i}$ & గุ & $\stackrel{\vec{p}}{\vec{p}}$ & $\stackrel{m}{+}$ & $\hat{\infty}$ & $\stackrel{+}{\stackrel{1}{1}}$ & $\begin{array}{c}n \\
\infty \\
\infty\end{array}$ & $\stackrel{n}{n}$ & $\stackrel{n}{\overline{1}}$ \\
\hline $\begin{array}{l}\dot{x} \\
\sum\end{array}$ & $\vec{b}$ & $\begin{array}{l}\infty \\
\dot{f} \\
\dot{f}\end{array}$ & $\underset{\mathcal{J}}{\tilde{J}}$ & $\stackrel{n}{m}$ & $\underset{\dot{m}}{\stackrel{\rho}{m}}$ & $\begin{array}{l}\stackrel{\infty}{\dot{q}} \\
\stackrel{+}{0}\end{array}$ & $\stackrel{\ddot{q}}{\ddot{q}}$ & $\begin{array}{l}\stackrel{\circ}{\dot{f}} \\
\dot{y}\end{array}$ & $\stackrel{\ddot{q}}{\dot{q}}$ & ז̇ & q & $\overline{\vec{\sigma}}$ & $\stackrel{i}{\dot{m}}$ & ウ̆. & $\stackrel{\vec{r}}{\grave{n}}$ & $\begin{array}{l}\infty \\
\stackrel{\text { }}{ }\end{array}$ & $\underset{\substack{+ \\
\text { di }}}{ }$ \\
\hline 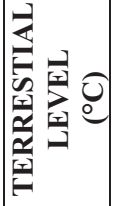 & $\begin{array}{l}\infty \\
\text { ते }\end{array}$ & $\overrightarrow{\mathrm{m}}$ & ָे & $\underset{\sim}{\tilde{\lambda}}$ & $\stackrel{\infty}{\dot{\sim}}$ & $\begin{array}{l}0 \\
\text { ì }\end{array}$ & $\stackrel{\circ}{\dot{d}}$ & $\stackrel{\text { I }}{\mathrm{d}}$ & $\hat{\ddot{\lambda}}$ & $\begin{array}{l}m \\
\infty \\
\infty\end{array}$ & $\begin{array}{l}\stackrel{0}{\infty} \\
\stackrel{\infty}{\rightarrow}\end{array}$ & $\vec{\infty}$ & $\hat{\bar{\lambda}}$ & 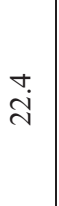 & $\stackrel{?}{=}$ & $\stackrel{+}{\vec{\sim}}$ & กิ \\
\hline 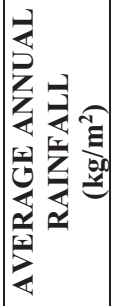 & $\widehat{\grave{d}}$ & $\begin{array}{l}\infty \\
\dot{\alpha} \\
\dot{\alpha}\end{array}$ & $\begin{array}{l}\stackrel{0}{0} \\
\stackrel{\text { वे }}{ }\end{array}$ & $\underset{\dot{\infty}}{\stackrel{+}{\alpha}}$ & $\begin{array}{l}\dot{\alpha} \\
\stackrel{\alpha}{\dot{q}}\end{array}$ & 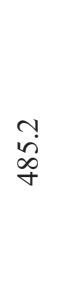 & $\begin{array}{l}\stackrel{0}{0} \\
\dot{+}\end{array}$ & ๙ֶ) & 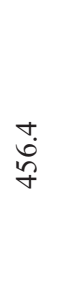 & 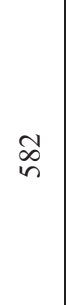 & ì & $\tilde{n}$ & $\vec{t}$ & $\stackrel{\hat{f}}{\hat{f}}$ & $\stackrel{\infty}{n}$ & ถి & $\stackrel{+}{n}$ \\
\hline 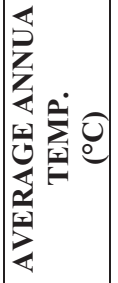 & ?ֵ & సુ & $\begin{array}{l}\text { I } \\
\dot{I}\end{array}$ & $\stackrel{\infty}{\stackrel{\sim}{\longrightarrow}}$ & $\stackrel{\text { I }}{ \pm}$ & $\begin{array}{l}\infty \\
\stackrel{+}{ \pm}\end{array}$ & $\stackrel{m}{\mathrm{I}}$ & 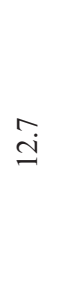 & $\stackrel{n}{\mathrm{I}}$ & ְై & $\stackrel{\infty}{\stackrel{\infty}{\Xi}}$ & $\stackrel{\Xi}{\beth}$ & $\stackrel{m}{n}$ & $\stackrel{n}{ \pm}$ & 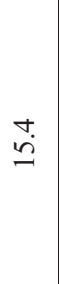 & $\stackrel{n}{ \pm}$ & $\stackrel{+}{ \pm}$ \\
\hline 昰 & $\gtreqless$ & 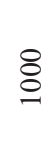 & $\hat{\circ}$ & త్ & है & $\stackrel{2}{i}$ & वे & $\stackrel{m}{\exists}$ & ले & $\stackrel{\infty}{\sim}$ & $n$ & 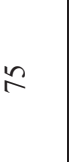 & 㐫 & $\bar{\sigma}$ & $\stackrel{\infty}{\sim}$ & $\stackrel{N}{ }$ & 은 \\
\hline
\end{tabular}

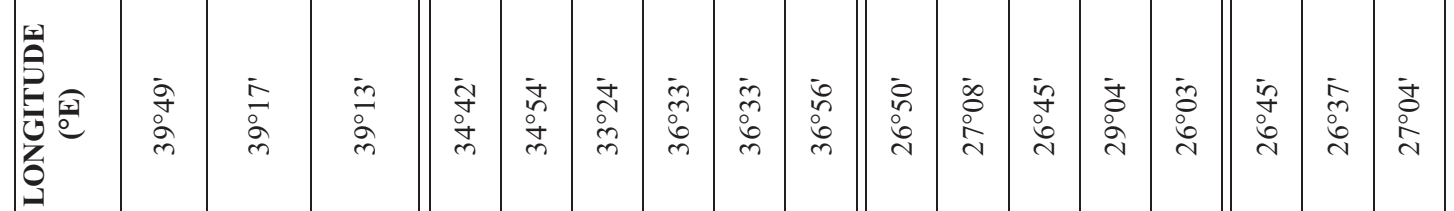

\begin{tabular}{|c|c|c|c|c|c|c|c|c|c|c|c|c|c|c|c|c|c|}
\hline 远 & $\begin{array}{l}\overline{1} \\
\infty \\
\infty \\
n\end{array}$ & $\begin{array}{l}\bar{m} \\
\stackrel{m}{\infty} \\
m\end{array}$ & $\begin{array}{l}\dot{j} \\
\text { o } \\
\infty \\
n\end{array}$ & $\begin{array}{l}\hat{\sigma} \\
\text { o } \\
\infty \\
n\end{array}$ & $\begin{array}{l}\bar{n} \\
\text { o } \\
\infty \\
n\end{array}$ & $\begin{array}{l}\overline{1} \\
0 \\
\dot{q} \\
\dot{q}\end{array}$ & $\begin{array}{l}\infty \\
\dot{\infty} \\
\dot{q}\end{array}$ & $\begin{array}{l}\dot{q} \\
\text { ò } \\
\text { o }\end{array}$ & $\begin{array}{l}\dot{q} \\
\text { on } \\
\stackrel{q}{q}\end{array}$ & 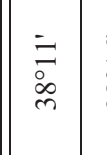 & $\begin{array}{l}0 \\
0 \\
\infty \\
\infty\end{array}$ & $\begin{array}{l}\dot{a} \\
\text { oे } \\
\text { m) }\end{array}$ & $\begin{array}{l}\text { वे } \\
\text { ò } \\
\text { n. }\end{array}$ & $\begin{array}{l}\bar{c} \\
\text { oे } \\
\infty \\
m\end{array}$ & $\begin{array}{l}\bar{y} \\
\text { वे } \\
\text { ले }\end{array}$ & $\begin{array}{l}\infty \\
\text { के } \\
\text { o } \\
\text { }\end{array}$ & $\begin{array}{l}\hat{\alpha} \\
\text { ô } \\
\text { ơ }\end{array}$ \\
\hline$\frac{n}{0}$ & 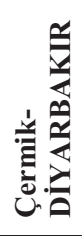 & 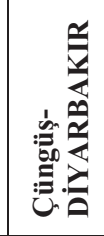 & טِّ & 童 & 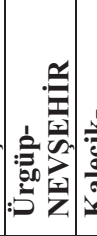 & | & 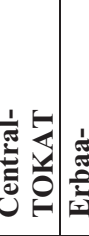 & 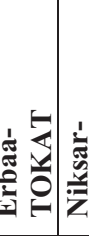 & . & 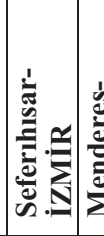 & 离 & 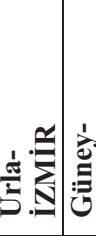 & ن. & 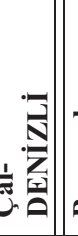 & 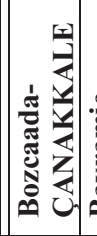 & 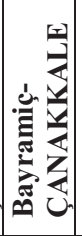 & טئ. \\
\hline 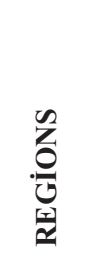 & N8B & $\begin{array}{l}\text { NOIOZ } \\
\text { NITOLV } \\
\text { NYALS } \\
\text { NV NOI } \\
\text { VITOL } \\
\text { ILSVAH }\end{array}$ & $\begin{array}{l}\text { U } \\
\text { NV } \\
\text { JG } \\
\text { OGy } \\
\text { NV } \\
\text { LOOS }\end{array}$ & & 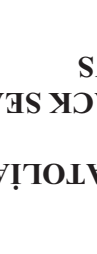 & $\begin{array}{l}\text { SNOI!? } \\
\text { OVTG } \\
\text { GNV } \\
\text { VNV }\end{array}$ & $\begin{array}{l}\text { OAd } \\
\text { TVYL } \\
\text { V } \\
\text { TVYL }\end{array}$ & $\begin{array}{l}\text { LNG } \\
\text { LNG }\end{array}$ & & & & $\begin{array}{l}\text { IOA4 } \\
\text { AOAV }\end{array}$ & & & $\begin{array}{r}\text { NO } \\
\text { V\&V }\end{array}$ & $\begin{array}{l}\text { OI!PA } \\
\text { Viny }\end{array}$ & $\begin{array}{l}\text { IX } \\
\text { VWW }\end{array}$ \\
\hline
\end{tabular}


Nevşehir (Central-Nevşehir and Ürgüp), Ankara (Kalecik) and Tokat (Central-Tokat, Erbaa and Niksar) three of the cities where important wine grapes are being produced in Central Anatolia and Central Black Sea Regions, have been the study area. Terrestial level varies from 21.8 (Ürgüp) -24.2 (Erbaa) according to the geographic and topographic conditions of the study area. The effects of the variety of the terrestial level, annual total rain and altitude difference have been observed. Average temperature value of the study area for many years have been measured between $12.3^{\circ} \mathrm{C}$ (CentralTokat) and $14.8^{\circ} \mathrm{C}$ in Kalecik (Table 2). Extremely high temperature values are between $38.9^{\circ} \mathrm{C}$ (Ürgüp) and $45.0^{\circ} \mathrm{C}$ (Central-Tokat, Erbaa and Niksar). Peak value of the low temperatures varies between $-22.4{ }^{\circ} \mathrm{C}$ (Ürgüp) and $-21.2^{\circ} \mathrm{C}$ (Central- Nevsşehir ) (Table 2).

Denizli (Güney and Çal) and İzmir (Menderes, Seferihisar, Urla) two of the cities where important wine grapes are being produced in the Aegean Region, have been the study area. Terrestial level varies from 18.3 (Urla) -22.4 (Çal) according to the geographic and topographic conditions of the study area. The effects of the variety of the terrestial level, annual total rain and altitude difference have been observed. Average temperature value of the study area for many years have been measured between $7.8^{\circ} \mathrm{C}$ (Menderes) and $14.5^{\circ} \mathrm{C}$ in Çal (Table 2). Extremely high temperature values are between $42.4^{\circ} \mathrm{C}$ (Seferihisar) and $39.4^{\circ} \mathrm{C}$ (Çal). Peak value of the low temperatures varies between $-10.0^{\circ} \mathrm{C}(\mathrm{Çal})$ and $-4.3^{\circ} \mathrm{C}$ (Urla) (Table 2).

Tekirdağ (Şarköy) and Çanakkale (Bozcaada and Bayramiç) two of the cities where important wine grapes are being produced in the Marmara Region, have been the study area. Terrestial level varies from 18.3 (Bozcaada) -21.4 (Bayramiç) according to the geographic and topographic conditions of the study area. The effects of the variety of the terrestial level, annual total rain and altitude difference have been observed. Average temperature value of the study area for many years have been measured between $14.4^{\circ} \mathrm{C}$ (Şarköy) and $15.4^{\circ} \mathrm{C}$ in Bozcaada (Table 2). Extremely high temperature values are between $39.8^{\circ} \mathrm{C}$ (Bayramiç) and $35.4^{\circ} \mathrm{C}$ (Bozcaada). Peak value of the low temperatures varies between $-13.5^{\circ} \mathrm{C}$ (Bayramiç) and $-8.2{ }^{\circ} \mathrm{C}$ (Bozcaada) (Table 2).

We assess the bio climatic values in the climatic surface in the regard of productions of the wine grape varieties in the Southeastern Anatolia Region and Eastern Anatolia Region (Table 3). It has been detected that the vegetation period starts between 23 March (Çüngüss) and 11 April (Central- ELAZIĞ). It has been understood that the potential vegetation duration was between 220 days (Central- ELAZIĞ) and 245 days (Çermik); and the total temperature was between $4525^{\circ} \mathrm{C}$ (Central- ELAZIĞ) and $5605^{\circ} \mathrm{C}$ (Çüngüs). Heliothermic indices, presenting the combination of the vegetation days and temperature factor, were high in all counties examined in the scope of the wine grape cultivation and that there were important differences between counties. The heliothermic indices values are between 6.25 (Central- ELAZIĞ) and 8.53 (Çermik) and these values are appropriate for the cultivation of the varieties of the wine grape cultivation in the examined area (according to the vegetation duration and Effective temperature).
The bio climatic values in the climatic surface in the regard of productions of the wine grape varieties in the Central Anatolia and Central Black Sea Regions (Table 3). It has been detected that the vegetation period starts between 09 April (Central- TOKAT and Niksar) and 2 April (Kalecik). It has been understood that the potential vegetation duration was between 199 days (CentralNEVŞEHIR) and 211 (Kalecik); and the total temperature was between $3528{ }^{\circ} \mathrm{C}$ (Ürgüp) and $4823^{\circ} \mathrm{C}$ (CentralTOKAT). The heliothermic indices values are between 6.15 (Kalecik) and 9.46 (Ürgüp) and these values are appropriate for the cultivation of the varieties of the wine grape cultivation in the examined area.

In the Aegean Region the bio climatic values in the climatic surface in the regard of productions of the wine grape varieties (Table 3) it has been detected that the vegetation period starts between 07 March (Menderes) and 06 April (Çal). It has been understood that the potential vegetation duration was between 205 days (Çal) and 255 days (Seferihisar); and the total temperature was between $4154^{\circ} \mathrm{C}$ (Çal) and $6425^{\circ} \mathrm{C}$ (Seferihisar). The heliothermic indices values are between 5.79 (Çal) and 9.15 (Seferihisar) and these values are appropriate for the cultivation of the varieties of the wine grape cultivation in the examined area.

The bio climatic values in the climatic surface in the regard of productions of the wine grape varieties in the Marmara Region (Table 3). It has been detected that the vegetation period starts between 25 March (Bozcaada) and 15 April (Şarköy). It has been understood that the potential vegetation duration was between 242 days (Bayramiç) and 280 days (Bozcaada); and the total temperature was between $5087^{\circ} \mathrm{C}$ (Bayramiç) and $5414^{\circ} \mathrm{C}$ (Bozcaada). The heliothermic indices values are between 6.47 (Bayramiç) and 7.53 (Bozcaaad) and these values are appropriate for the cultivation of the varieties of the wine grape cultivation in the examined area.

A parallelism has been found between the counties of Regions of Turkey in terms of precipitation amount and dispersion in the vegetation period. It is seen that wine grape cultivation is possible in the examined regions without watering in the wine grape growing.

As a result of the assessment made in Southeastern Anatolia Region and Eastern Anatolia Region it was seen that the the effective heat summation (EHS) was between $2315^{\circ} \mathrm{C}$ and $2914^{\circ} \mathrm{C}$ (Table 3). The temperature need of Boğazkere grape variety was $1252^{\circ} \mathrm{C}$ (Table 4) and temperature need of Öküzgözü grape variety was $1542^{\circ} \mathrm{C}$. Total efficient temperature in Çermik county was $2874^{\circ} \mathrm{C}$ and EHS of Çüngüss county was $2914^{\circ} \mathrm{C}$ in Diyarbakır. The total efficient temperature of Central-ELAZIĞ in Eastern Anatolia Region county was $2315^{\circ} \mathrm{C}$ and the total temperature needs of the varieties were as follows: Öküzgözü $1542{ }^{\circ} \mathrm{C}$, Boğazkere $1525^{\circ} \mathrm{C}$ (Table 4). The effective heat summation need of these grape varieties demand a lower total temperature than in Southeastern Anatolia Region and Eastern Anatolia Region effective heat summation values.

In the Central Anatolia and Central Black Sea Regions it was seen that the EHS was between $2137^{\circ} \mathrm{C}$ and $2961^{\circ} \mathrm{C}$ (Table 3). EHS in Central-Nevşehir county was $2874^{\circ} \mathrm{C}$ and EHS of Ürgüp county was $2914^{\circ} \mathrm{C}$ in Nevşehir. The EHS need of grape varieties were as follows: $1400^{\circ} \mathrm{C}$ 


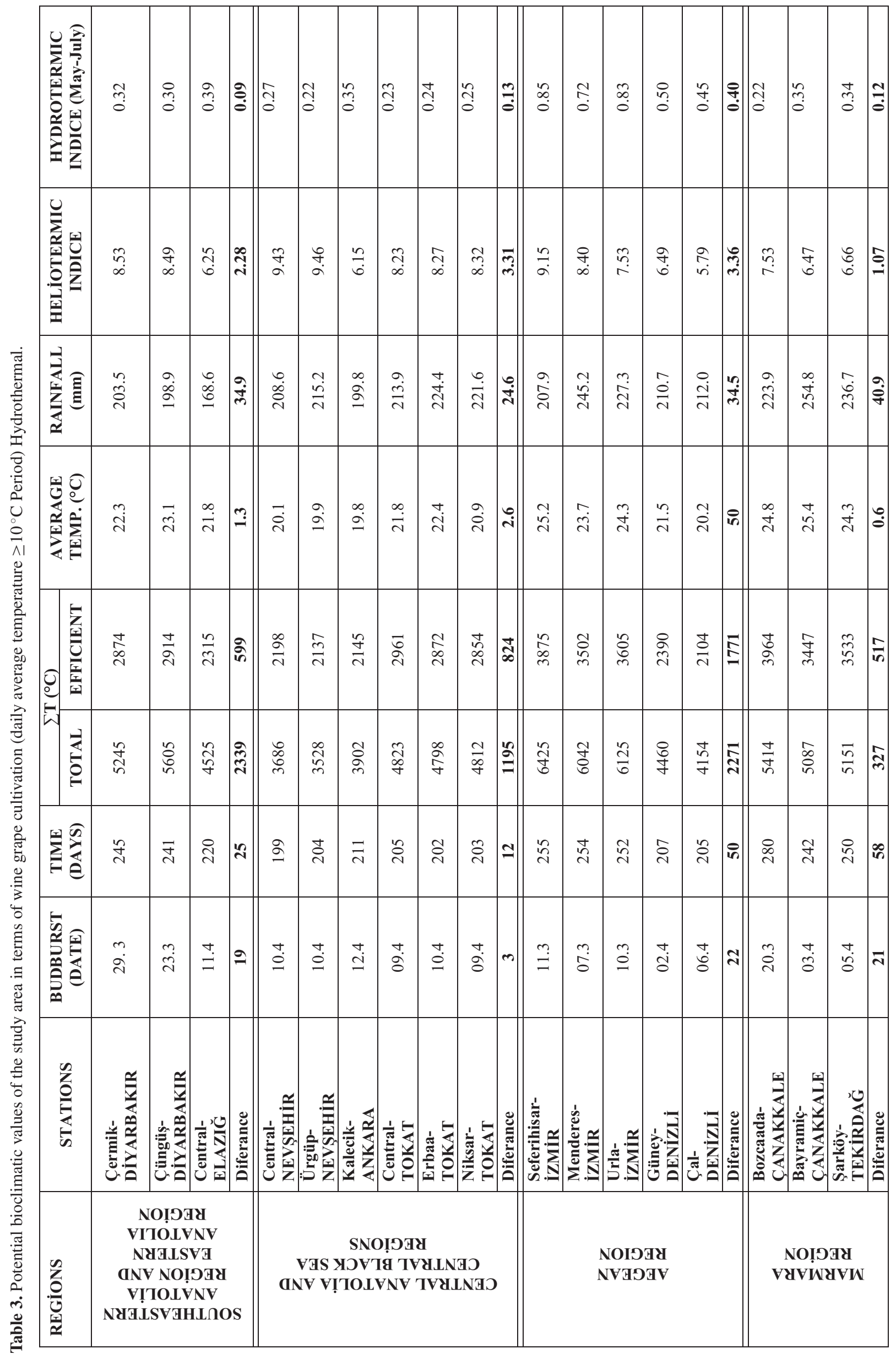


Table 4. Features of some grape wine varieties and their temperature needs (Çelik at all, 1988a).

\begin{tabular}{|l|c|}
\hline Wine Grape Varieties & Temperature Needs ${ }^{\circ}$ C) \\
\hline Alicante Bouschet & 1398 \\
\hline Boğazkere & $\mathbf{1 5 2 5}$ \\
\hline Bornova Misketi & $\mathbf{1 2 5 0}$ \\
\hline Cabernet Sauvignon & 1382 \\
\hline Carignan & 1547 \\
\hline Cinsaut & 1453 \\
\hline Çal Karası & $\mathbf{1 3 9 5}$ \\
\hline Dimrit & $\mathbf{1 4 0 0}$ \\
\hline Emir & $\mathbf{1 5 0 2}$ \\
\hline Gamay & 1363 \\
\hline Kalecik Karası & $\mathbf{1 4 2 1}$ \\
\hline Karalahana & $\mathbf{1 5 3 5}$ \\
\hline Karasakız & $\mathbf{1 5 2 2}$ \\
\hline Merlot & 1402 \\
\hline Semilion & 1382 \\
\hline Narince & $\mathbf{1 4 1 8}$ \\
\hline Sultani Çekirdeksiz & $\mathbf{1 3 8 0}$ \\
\hline Syrah & 1399 \\
\hline Vasilaki & $\mathbf{1 4 3 5}$ \\
\hline Yapıncak & $\mathbf{1 5 4 5}$ \\
\hline
\end{tabular}

(Dimrit), $1502{ }^{\circ} \mathrm{C}$ (Emir) and $1421^{\circ} \mathrm{C}$ (Kalecik Karas1) (Table 4). EHS of Kalecik county was $2145^{\circ} \mathrm{C}$. The temperature need of Kalecik Karasigrape variety was $1421^{\circ} \mathrm{C}$ (Table 4). EHS in Central TOKAT county was $2961{ }^{\circ} \mathrm{C}$ and EHS of Erbaa county was $2872^{\circ} \mathrm{C}$ and EHS of Niksar county in Tokat. The temperature need of Narince grape variety was $1418^{\circ} \mathrm{C}$ (Table 4). The effective heat summation need of these grape varieties demand a lower total temperature than effective heat summation values.of in the Central Anatolia and Central Black Sea Regions.

In Aegean region it was seen that the EHS was between $2104^{\circ} \mathrm{C}$ and $3875^{\circ} \mathrm{C}$ (Table 3) and the temperature need of Alicante Bouschet grape variety was $1398^{\circ} \mathrm{C}$ (Table 4) and temperature need of Carignan grape variety was $1547^{\circ} \mathrm{C}$. Total efficient temperature in Urla county was $3605^{\circ} \mathrm{C}$ and the needs of grape varieties were as follows: Cabernet Sauvignon $1382^{\circ} \mathrm{C}$, Syrah $1399^{\circ} \mathrm{C}$ and Alicante Bouschet $1398^{\circ} \mathrm{C}$ (Table 4). EHS of Güney county in Denizli was $2390^{\circ} \mathrm{C}$ and the temperature needs of the varieties are as follows: Syrah $\left(1399^{\circ} \mathrm{C}\right)$, Kalecik Karası $\left(1421^{\circ} \mathrm{C}\right)$, Boğazkere $\left(1525^{\circ} \mathrm{C}\right)$, Merlot $\left(1402^{\circ} \mathrm{C}\right)$, Öküzgözü $\left(1542^{\circ} \mathrm{C}\right)$, Cabernet Sauvignon $\left(1382^{\circ} \mathrm{C}\right)$, Çalkarası $\left(1395^{\circ} \mathrm{C}\right)$ and Sultani Çekirdeksiz $\left(1380^{\circ} \mathrm{C}\right)$ and the temperature need of these grape varieties demand a lower total temperature than these values. The total efficient temperature of Çal county was $2104^{\circ} \mathrm{C}$ and the total temperature needs of the varieties were as follows: Öküzgözü $1542^{\circ} \mathrm{C}$, Çal Karas $1\left(1395^{\circ} \mathrm{C}\right)$, Boğazkere $1525^{\circ} \mathrm{C}$, Merlot $1402^{\circ} \mathrm{C}$ and Sultani Çekirdeksiz $\left(1380^{\circ} \mathrm{C}\right)$ (Table 4$)$. The effective heat summation need of these grape varieties demand a lower total temperature than effective heat summation values of Aegean region.
In Marmara region it was seen that the EHS was between $3447{ }^{\circ} \mathrm{C}$ and $3964^{\circ} \mathrm{C}$ (Table 3). The effective heat summation of Bozcaada county in Çanakkale was $4964^{\circ} \mathrm{C}$ and the effective heat summation need of grape varieties were as follows: Alicante Bouschet, $1398^{\circ} \mathrm{C}$, Cabernet Sauvignon $1382^{\circ} \mathrm{C}$, Karalahana $1535^{\circ} \mathrm{C}$, Karasakız $1522^{\circ} \mathrm{C}$, Merlot $1402^{\circ} \mathrm{C}$, Syrah $1399^{\circ} \mathrm{C}$, and Vasikali $1435^{\circ} \mathrm{C}$ (Table 4). The effective heat summation of Bayramiç county in Çanakkale was $3447^{\circ} \mathrm{C}$ and the effective heat summation need of grape varieties were as follows: Cabernet Sauvignon $1382^{\circ} \mathrm{C}$, Karasakız $1522^{\circ} \mathrm{C}$. The total efficient temperature of Şarköy county in Tekirdag was $3533^{\circ} \mathrm{C}$ and the effective heat summation need of grape varieties were as follows: Cabernet Sauvignon $1382^{\circ} \mathrm{C}$, Cinsaut $1453^{\circ} \mathrm{C}$, Gamay $1363^{\circ} \mathrm{C}$, Merlot $1402^{\circ} \mathrm{C}$ Semilion $1382^{\circ} \mathrm{C}$, Yapıncak $1545^{\circ} \mathrm{C}$, (Table 4). The effective heat summation need of these grape varieties demand a lower total temperature than effective heat summation values of Marmara region.

According to the climatic data from the meteorological station and the evaluation carried out with the wine grape growers has been found that Boğazkere, and Öküzgözü in the region of Southeastern Anatolia and Eastern Anatolia Region; Kalecik Karası, Dimrit and Narince in Central Anatolia Region and Emir in the Central Black Sea Region; Bornova Misketi, Cabernet Sauvignon, Syrah, Alicante Bouschet, Carignane, Kalecik Karası, Merlot, Öküzgözü, Çal Karası, Boğazkere, Sultani Çekirdeksiz in Aegean Region; Karasakız, Karalahana, Vasilaki, Cabernet Sauvignon, Merlot, Syrah, Alicante Bouschet, Semillion, Cinsaut, Yapıncak, Gamay, Merlot, Cabernet Sauvignon can be adapt and grow well in terms of climatic conditions in Marmara Region respectively.

\section{References}

[1] TUİK, (Turkish Statistical Institute), Agricultural Production Statistics. (www . tuik.gov.tr) (2015)

[2] J., Branas, Viticulture 343-357 (1974)

[3] G.H. Constantinescu, Bulletin de I'OIV 40, 441 (1967)

[4] P. Huglin, 'Biologie et écologie de la vigne.' (Payot Editions:Lausanne, France) 264-309 (1986)

[5] H. Işık, Üzüm Çeşidi ve Uyumlu Yer Seçimine ilişkin V. Vinifera L. Üzerine Biyoklimatik Araştırma. Science Title Thesis. Pleven (1988)

[6] H. Işık, H. Öztürk, Gökçay, E., Kader, S., Ege Bölgesinde Sofralık Üzüm Yetiştiriciliğine İlişkin Biyoklimatik Araştırmalar. Manisa Bağcılık Araştırma Enstitüsü, Final Report Manisa (2001a)

[7] H. Iş1k, N.Y. Delice, C. Özer., Sofralık Üzüm Çeşitlerinin Marmara Bölgesi Koşullarına Biyoekolojik иуити ile Muhafaza ve Pazarlama Sorunları̈̈zerinde Araştırmalar. Final Report Tekirdağ. (2001b)

[8] C. Van Leeuwen, C. Garnier Agut, B. Baculat, G. Barbeau, E. Besnard, B.Bois, J.-M. Boursiquot, I. Chuine, T. Dessup, T. Dufourcq, I. GarciaCortazar, E. Marguerit, C.Monamy, S. Koundouras, J.-C Payan., A. Parker, V. Renouf, B. RodriguezLovelle, J.-P. Roby, J. Tonietto, and W. Trambouze, 
Proceedings of the 7th International Terroir Congress, Changins, Switzerland (Agroscope ChanginsWädenswil: Switzerland) pp. 222-227 (2008)

[9] A.J. Winkler, J.A. Cooke, M. Kliewer, L.A. Lider, General viticulture, California Uni. Pres. 710 p. (1974)

[10] H., Çelik, Y.S., Y., Ağaoğlu, Fidan, B., Marasalı., G.,Söylemezoğlu, Genel Bağcılık, 253 s. ANKARA (1998)
[11] H. Uzun, Journal of The Faculty of Agriculture, Akdeniz University 9, 40-60 (1996)

[12] M.N. Oraman, 1970. Bağcılık Tekniği I. Ankara university agricultural faculty publications number: 415, Ankara (1970)

[13] H. Çelik, B. Marasalı, İ.Demir, Türkiye III. Bağcılık Sempozyumu, Bursa (1988)

[14] N. Karantonis, 1.er Symposium International su I'Ecologie de la Vigne, Constanta (1978) 